\title{
BINDING OF TYPE-III GROUP-B STREPTOCOCCI TO BUCCAL EPITHELIAL CELLS
}

\author{
J. Bagg, I. R. Poxton, D. M. Weir And P. W. Ross
}

\section{Department of Bacteriology, Medical School, Teviot Place, Edinburgh EH8 $9 A G$}

\begin{abstract}
Summary. A binding assay was used to study the attachment of type-III group-B streptococci (GBS) to buccal epithelial cells. Results indicate that an adhesin, with the characteristics of a protein, is the molecule at the streptococcal cell surface responsible for attachment to the buccal cells. The bacterial adhesin probably recognises a sugar on the surface of the mucosal cell, because periodate oxidation of the buccal cells caused a significant reduction in subsequent adherence of GBS. A sonicate of type-III GBS blocked the binding of the organism to buccal cells. The effects of physical and chemical modifications of the sonicate on its ability to prevent bacterial attachment are described; these corroborate the evidence gained from heat and periodate treatments of the buccal cells and GBS. Results suggest a lectin type of attachment mechanism for type-III GBS which can be blocked by N-acetyl-D-glucosamine, rather than attachment by means of a lipoteichoic acid as described for group-A streptococci.
\end{abstract}

\section{INTRODUCTION}

It is widely accepted that adherence of bacteria to mucosal cells is important in the initiation of many types of microbial disease (Gibbons and van Houte, 1971). Group-B streptococci (GBS) are an important cause of serious neonatal illness (Anthony and Okada, 1977), which has been related to vaginal colonisation with these organisations (Ferrieri, Cleary and Seeds, 1977); several authors have reported the kinetics of the binding reaction between isolated vaginal epithelial cells and GBS (Mårdh and Weström, 1976; Zawaneh et al., 1979). It has also been shown that the degree of attachment between bacteria and vaginal cells is related to the hormonal status of the vaginal-cell donor, reaching a maximum near the time of ovulation (Botta, 1979). At present, little is known of the particular bacterial cell-surface components concerned in the binding of GBS to epithelial cells. In group-A streptococci, membrane lipoteichoic acid (LTA) at the surface of the bacteria, is responsible, at least in part, for their adherence to buccal epithelial cells (BEC) (Beachey, 1975). This paper describes features of the binding of GBS to BEC and indicates the nature of the adhesin on the GBS cell surface that mediates attachment of the organism to BEC. 


\section{MATERIALS AND METHODS}

Bacteria. Type-III GBS (strain NCTC11080) and group-A streptococcus (strain NCTC10085) were from the National Collection of Type Cultures, Colindale Avenue, London NW9 5HT and were grown in static culture for $18 \mathrm{~h}$ at $37^{\circ} \mathrm{C}$ in Todd-Hewitt Broth (Oxoid CM189).

Buccal cells were gently scraped with a wooden spatula from the inside of the cheek of a healthy male donor and suspended in $10 \mathrm{ml}$ of Dulbecco's Phosphate-buffered Saline (PBS; Oxoid BR 14a). The suspension was placed in a thin-walled test tube and treated in a sonic water bath (Model 6441 A, Dawe Inst. Ltd, Concord Road, Western Avenue, London W3 0SD) for $1 \frac{1}{2}$ min to aid the removal of background commensal organisms. The cells were then sedimented at $200 \mathrm{~g}$ for $10 \mathrm{~min}$ and washed twice more in PBS. The washed pellet was suspended in $2 \mathrm{ml}$ of PBS and a cell count performed in a Neubauer counting chamber. The suspension was finally adjusted to a concentration of $2-6 \times 10^{4}$ cells $/ \mathrm{ml}$ by dilution with PBS.

Adherence assay. The extinction at $650 \mathrm{~nm}\left(E_{650}\right)$ of the 18 -h culture of GBS was adjusted to 0.43 which, from a previously determined calibration curve, yielded $10^{8} \mathrm{cfu} / \mathrm{ml}$. The volume was noted. The bacteria were sedimented at $900 \mathrm{~g}$ for $20 \mathrm{~min}$, washed once in PBS, then resuspended to $10^{8} \mathrm{cfu} / \mathrm{ml}$ in the previously noted volume of Dulbecco's PBS + Dulbecco "B" solution (Oxoid SR39) $0.5 \mathrm{ml} / 100 \mathrm{ml}$ of PBS.

Samples of bacterial suspension $(1 \mathrm{ml})$ were mixed with equal volumes of buccal-cell suspension in small, flat-bottomed sample tubes; the stoppered tubes were rotated at $30 \mathrm{rpm}$ at $37^{\circ} \mathrm{C}$ for $45 \mathrm{~min}$. After incubation, each mixture was filtered through a $10-\mu \mathrm{m}$ filter (Gelman Sciences Inc., $600 \mathrm{~S}$. Wagner Road, Ann Arbor, Michigan; polypropylene filter, 13-mm diameter) held in a Millipore filter holder, mounted on the end of a 10-ml syringe. Each filter was washed with $30 \mathrm{ml}$ of PBS, carefully removed from the filter holder and inverted onto a drop of PBS on a clean microscope slide. The filters were lifted off the slide after approximately 2 min. The slides were air-dried, fixed in methanol for $5 \mathrm{~min}$, and finally stained by Gram's method. The stained smears were mounted in DPX (dibutyl thallate xylol) under coverslips.

Each mixture of bacteria and buccal cells was prepared in duplicate and the results were averaged. Counting was performed at a magnification of 400 and for each experiment the bacteria adherent to each of 100 separate buccal cells was counted. Statistical significance was tested by Student's $t$ test.

Preparation of sonicate from GBS. GBS were grown for $18 \mathrm{~h}$ in $3 \mathrm{~L}$ of Todd-Hewitt broth, at $37^{\circ} \mathrm{C}$. Bacteria were harvested by centrifugation at $20000 \mathrm{~g}$ for $10 \mathrm{~min}$, washed once in PBS $(p \mathrm{H}$ $7 \cdot 4,0.01 \mathrm{M})$ and suspended in $20 \mathrm{ml}$ of PBS. The resulting suspension was treated in $5-\mathrm{ml}$ portions in the sonic waterbath for $5 \mathrm{~min}$ and the cells were then sedimented at $20000 \mathrm{~g}$ for 10 min. The supernate was collected and dialysed against $0 \cdot 005 \mathrm{M}$ tris- $\mathrm{HCl}$ buffer $(p \mathrm{H} \mathrm{7.4})$ for $3 \frac{1}{2} \mathrm{~h}$ at $4{ }^{\circ}$. The material was then lyophilised.

Heat-treated sonicate was prepared by autoclaving at $121^{\circ} \mathrm{C}$ for $15 \mathrm{~min}$. For periodate oxidation of the sonicate, a $2-\mathrm{ml}$ sample (protein $140 \mu \mathrm{g} / \mathrm{ml}$ in $0.01 \mathrm{M} \mathrm{PBS}, p \mathrm{H} \mathrm{7.4}$ ) was made $0.1 \mathrm{M}$ in sodium metaperiodate and left overnight at room temperature, in the dark. Excess periodate was destroyed by treatment with ethylene glycol, followed by lyophilisation. The sample was then re-dissolved in $2 \mathrm{ml}$ of distilled water. A control sample was treated in the same way except that periodate was not added.

Preparation of membrane lipoteichoic acid. LTA was extracted from the cytoplasmic membrane of type-III GBS with cold $80 \%$ aqueous phenol and purified on a column of Sepharose 6B by the method of Coley, Duckworth and Baddiley (1975).

Pretreatment of $G B S$. Bacterial suspensions were treated with periodate for $5 \mathrm{~min}$ at room temperature in $4 \mathrm{ml}$ of acetate buffer, $p \mathrm{H} 4 \cdot 6$, containing sodium meta-periodate $10 \mathrm{mg} / \mathrm{ml}$. Control organisms were suspended in the same buffer but which did not contain periodate. The bacteria were then washed once in PBS before being resuspended in Dulbecco's PBS + "B" to the required concentration. Bacteria were either heated in a $75^{\circ} \mathrm{C}$ water bath for $30 \mathrm{~min}$ or in an autoclave to $121^{\circ} \mathrm{C}$ for $15 \mathrm{~min}$.

Bacteria were treated with trypsin (E.C. 3,4,21,4, Type III Sigma Chemical Co.) at a concentration of $10000 \mathrm{~N}$-benzoyl-L-arginine ethyl ester units $/ \mathrm{ml}$ in $46 \mathrm{~mm}$ tris- $\mathrm{HCl}(p \mathrm{H} \mathrm{7.5)}$ containing $11.5 \mathrm{mM} \mathrm{CaCl}_{2}$ for $1 \mathrm{~h}$ at $37^{\circ} \mathrm{C}$ by the method of Saunders and Miller (1980).

Pretreatment of bacteria with various sugars was by incubation, at $37^{\circ} \mathrm{C}$, of washed cells with 
the relevant sugar, dissolved in Dulbecco's PBS + "B". Bacteria were washed once in Dulbecco's PBS+ "B" before the adherence assay.

Pretreatment of buccal cells. Washed BEC were treated with streptococcal sonicate by mixing the cells with the sonicate on a tube rotator at $37^{\circ} \mathrm{C}$ for $1 \mathrm{~h}$. The buccal cells were then sedimented by centrifugation at $200 \mathrm{~g}$ for $10 \mathrm{~min}$.

Buccal cells were treated with LTA $0.7 \mathrm{mg} / \mathrm{ml}$ in the same manner as was the sonicate. Periodate treatment of the buccal cells was performed in the same way as for the GBS.

Analytical procedures. Protein concentration was estimated by the method of Lowry et al. (1951).

Polyacrylamide-gel electrophoresis (PAGE) was done in the presence of $1 \%$ sodium dodecyl sulphate (SDS) on $10 \%$ polyacrylamide slab gels with the discontinuous buffer system of Laemmli and Favre (1973). The gels were stained for protein with Coomassie brilliant blue R. A mixture of reference proteins (BDH, Poole, Dorset BH12 4NN) containing cytochrome C (mol. wt 12 300), myoglobin (17 200), chymotrypsinogen A (25 700), ovalbumin (45 000), albumin (66 200) and ovotransferrin (76-78 000) was used as an indicator of molecular weights.

\section{RESULTS}

In preliminary experiments to confirm that GBS would adhere to BEC, their adherence was compared with that of group-A streptococci, which previously have been shown to become bound to BEC (Alkan, Ofek and Beachey, 1977). There was no statistically significant difference $(p>0 \cdot 1)$ between the number of these two organisms binding to BEC (table I).

TABLE I

Adherence of group-A streptococci and type-III GBS to human BEC

\begin{tabular}{l|c}
\hline \multicolumn{1}{c|}{ Bacterial cells } & $\begin{array}{c}\text { Mean* number of bacteria attached } \\
\text { per epithelial cell } \pm 2 \text { SEM }\end{array}$ \\
\hline None (background) & $2 \cdot 3 \pm 0 \cdot 6$ \\
Type-III GBS & $13 \cdot 9 \pm 2 \cdot 5$ \\
Group-A streptococci & $15 \cdot 7 \pm 3 \cdot 2$ \\
\hline
\end{tabular}

GBS = group-B streptococci; $\mathrm{BEC}=$ buccal epithelial cells.

* Of count on 100 epithelial cells.

The kinetics of the binding reaction between BEC and type-III GBS, determined by incubating mixtures of GBS and BEC for 5, 15, 25, 35, 45, 60 and 90 min respectively, are shown in fig. 1. Maximum adherence was reached after $45 \mathrm{~min}$ with no significant increase after incubation for $90 \mathrm{~min}$.

\section{Periodate treatment of $B E C$}

Treatment of BEC with sodium meta-periodate caused a significant decrease $(\mathrm{p}<0.001)$ in the binding of type-III GBS to the cells (table II).

\section{Pretreatment of bacteria}

Periodate treatment of type-III GBS did not cause a decrease in binding to BEC. Mild heat treatment of bacteria, $75^{\circ} \mathrm{C}$ for $30 \mathrm{~min}$, did not decrease the binding either but autoclaving at $121^{\circ} \mathrm{C}$ for $15 \mathrm{~min}$ reduced binding to a very low level; the difference 


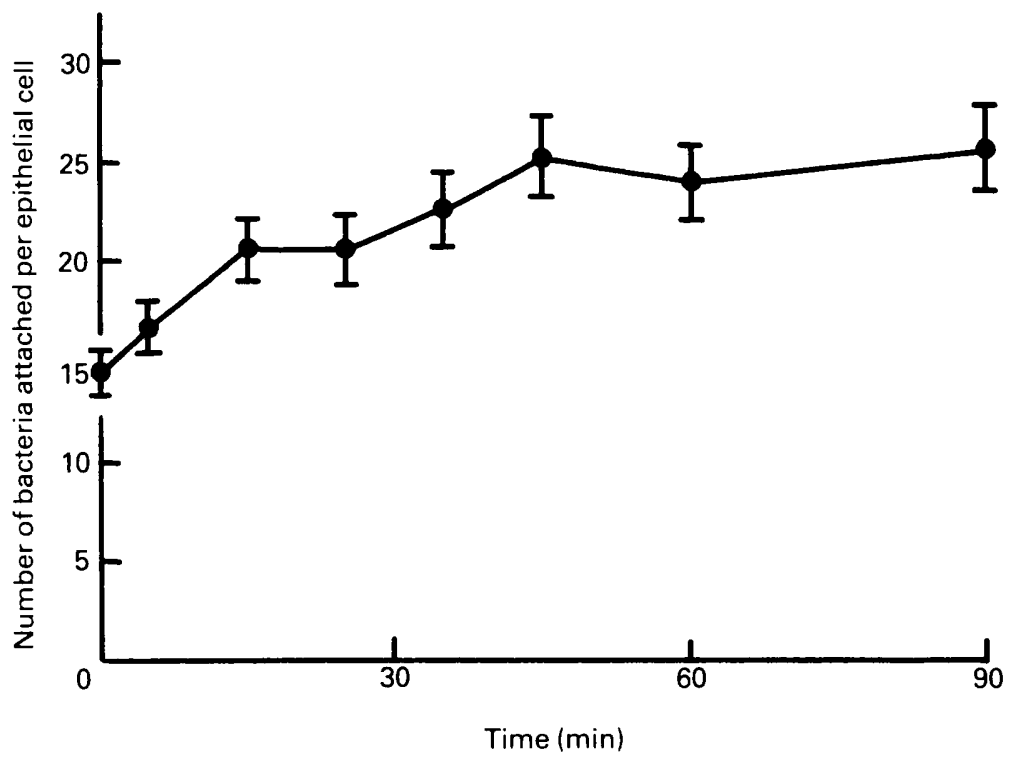

FIG. 1.-Effect of incubation time on adherence of type-III GBS to BEC. Each point represents the geometric mean $( \pm 1 \mathrm{SE})$ of results from 100 buccal cells.

was statistically highly significant $(p<0 \cdot 001)$. Treatment of GBS with trypsin caused a significant decrease $(p<0.01)$ in their subsequent adherence to BEC. These results are shown in table III.

\section{Blocking of adherence with sonicate from type-III GBS}

Preincubation of BEC with the sonicate preparation blocked the binding of type-III GBS in a dose-response fashion (fig. 2).

Treatment of the sonicate at $121^{\circ} \mathrm{C}$ for 15 min significantly reduced its ability to block bacterial binding $(\mathrm{p}<0.001)$, but periodate oxidation of the sonicate affected its blocking capacity much less (table IV). Because there was no significant difference ( $p>0 \cdot 1$ ) between the activities of the periodate-treated sonicate and the periodate-control sonicate, it seems unlikely that a carbohydrate on the bacterial surface is concerned in adhesion.

TABLE II

Effect of periodate treatment of BEC on subsequent adherence of type-III GBS

\begin{tabular}{l|c}
\hline \multicolumn{1}{c|}{ Cells } & $\begin{array}{c}\text { Mean* number of bacteria attached } \\
\text { per epithelial cell } \pm 2 \text { SEM }\end{array}$ \\
\hline None (background) & $10 \cdot 8 \pm 1 \cdot 9$ \\
Periodate-treated & $10 \cdot 1 \pm 1 \cdot 6$ \\
BEC (background) & $19 \cdot 3 \pm 2 \cdot 8$ \\
BEC+GBS & $13 \cdot 0 \pm 1 \cdot 9$ \\
Periodate-treated & \\
\hline BEC + GBS & \\
\hline
\end{tabular}

Footnotes as in table I. 
TABLE III

Effect of pretreatment of type-III GBS on their adherence to BEC

\begin{tabular}{l|c}
\hline \multicolumn{1}{c|}{ Bacterial cells } & $\begin{array}{c}\text { Mean* number of bacteria attached } \\
\text { per epithelial cell } \pm 2 \text { SEM }\end{array}$ \\
\hline None (background) & $19 \cdot 9 \pm 3 \cdot 4$ \\
GBS & $26 \cdot 5 \pm 3 \cdot 2$ \\
Periodate-treated GBS & $30 \cdot 0 \pm 4 \cdot 4$ \\
None (background) & $21 \cdot 4 \pm 3 \cdot 2$ \\
GBS & $30 \cdot 5 \pm 3 \cdot 4$ \\
Mildly heated $\dagger$ GBS & $35 \cdot 4 \pm 3 \cdot 5$ \\
None (background) & $19 \cdot 2 \pm 2 \cdot 6$ \\
GBS & $30 \cdot 5 \pm 3 \cdot 4$ \\
Autoclaved $\ddagger$ GBS & $20 \cdot 0 \pm 2 \cdot 0$ \\
None (background) & $24 \cdot 5 \pm 3 \cdot 2$ \\
GBS & $40 \cdot 8 \pm 5 \cdot 9$ \\
Trypsinised GBS & $30 \cdot 8 \pm 3 \cdot 6$ \\
\hline
\end{tabular}

$+75 \mathrm{C}$ for $30 \mathrm{~min}$.

$\ddagger 121 \mathrm{C}$ for $15 \mathrm{~min}$

Other footnotes as in table I.

\section{Inhibition of adherence by sugars}

Of all the sugars tested $(0 \cdot 2 \mathrm{M}$ D-galactose, $0 \cdot 2 \mathrm{M}$ L-fucose, $0 \cdot 05 \mathrm{M}$ lactose, $0 \cdot 2 \mathrm{M}$ D-glucose, $0 \cdot 2 \mathrm{M} \alpha$-methyl-D-mannoside, $0 \cdot 2 \mathrm{M}$ maltose, $0 \cdot 1 \mathrm{M} \mathrm{N}$-acetyl-D-galactosamine and $0.1 \mathrm{M}$ N-acetyl-D-glucosamine), only N-acetyl-D-glucosamine produced a

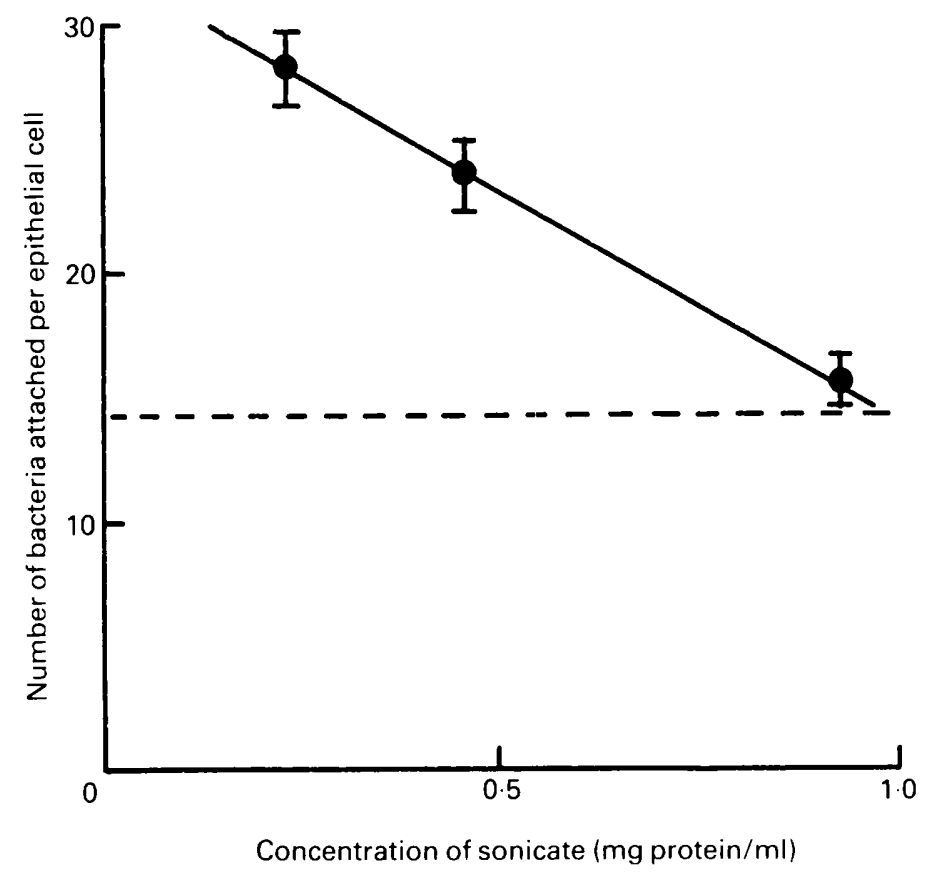

FIG. 2.-Dose-response curve of inhibition of binding by type-III GBS sonicate. Each point represents the geometric mean $( \pm 1 \mathrm{SE})$ of results from 100 buccal cells. $---=$ background. 
TABLE IV

Effect of heat and periodate oxidation on the capacity of type-III GBS sonicate to block binding of type-III GBS to BEC

\begin{tabular}{l|c}
\hline \multicolumn{1}{c|}{$\begin{array}{c}\text { Epithelial and } \\
\text { bacterial cells }\end{array}$} & $\begin{array}{c}\text { Mean* } \\
\text { number of bacteria attached per } \\
\text { epithelial cell } \pm 2 \text { SEM }\end{array}$ \\
\hline Untreated BEC (background) & $2 \cdot 6 \pm 1 \cdot 4$ \\
Untreated BEC+GBS & $8 \cdot 5 \pm 1 \cdot 6$ \\
Sonicate-treated BEC+GBS & $3 \cdot 2 \pm 0 \cdot 5$ \\
Heated $\dagger$ sonicate-treated & $6 \cdot 7 \pm 0 \cdot 9$ \\
BEC+GBS & $5 \cdot 0 \pm 0 \cdot 8$ \\
Periodate-oxidised sonicate- & \\
treated BEC+GBS & $4 \cdot 2 \pm 1 \cdot 1$ \\
Unoxidised control sonicate- \\
treated BEC+GBS
\end{tabular}

$+121^{\circ} \mathrm{C}$ for $15 \mathrm{~min}$.

Other footnotes as in table I.

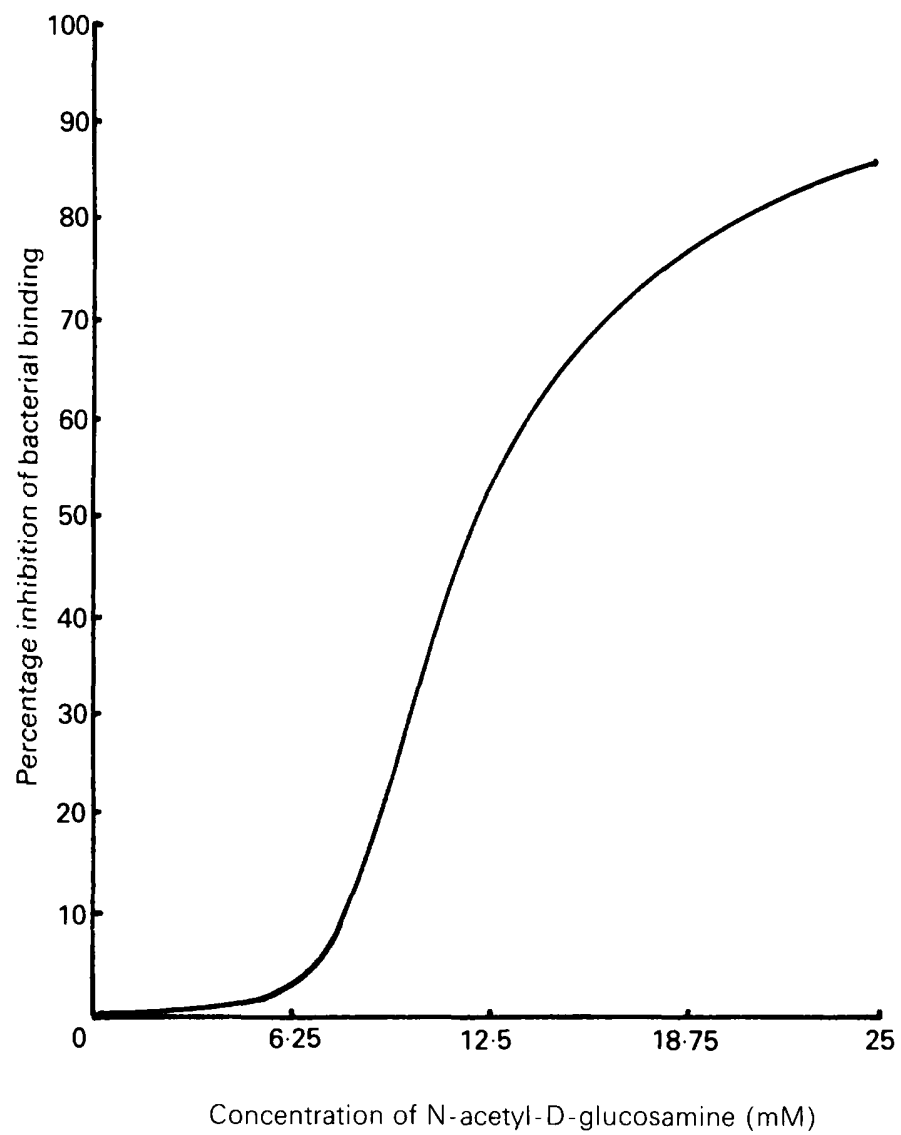

FIG. 3.-Dose-response curve of inhibition of binding of type-III GBS to BEC by N-acetyl-D-glucosamine. Means of three counts. 
TABLE V

Effect of pretreatment of BEC with type-III GBS membrane LTA on subsequent adherence of type III-GBS

\begin{tabular}{l|c}
\hline \multicolumn{1}{c|}{$\begin{array}{c}\text { Epithelial and } \\
\text { bacterial cells }\end{array}$} & $\begin{array}{c}\text { Mean* number of bacteria attached } \\
\text { per epithelial cell } \pm 2 \text { SEM }\end{array}$ \\
\hline Untreated BEC (background) & $22 \cdot 2 \pm 2 \cdot 6$ \\
LTA-treated BEC + GBS & $28 \cdot 9 \pm 3 \cdot 8$ \\
Untreated BEC + GBS & $33 \cdot 0 \pm 3 \cdot 2$ \\
\hline
\end{tabular}

LTA $=$ lipoteichoic acid.

Other footnotes as in table I.

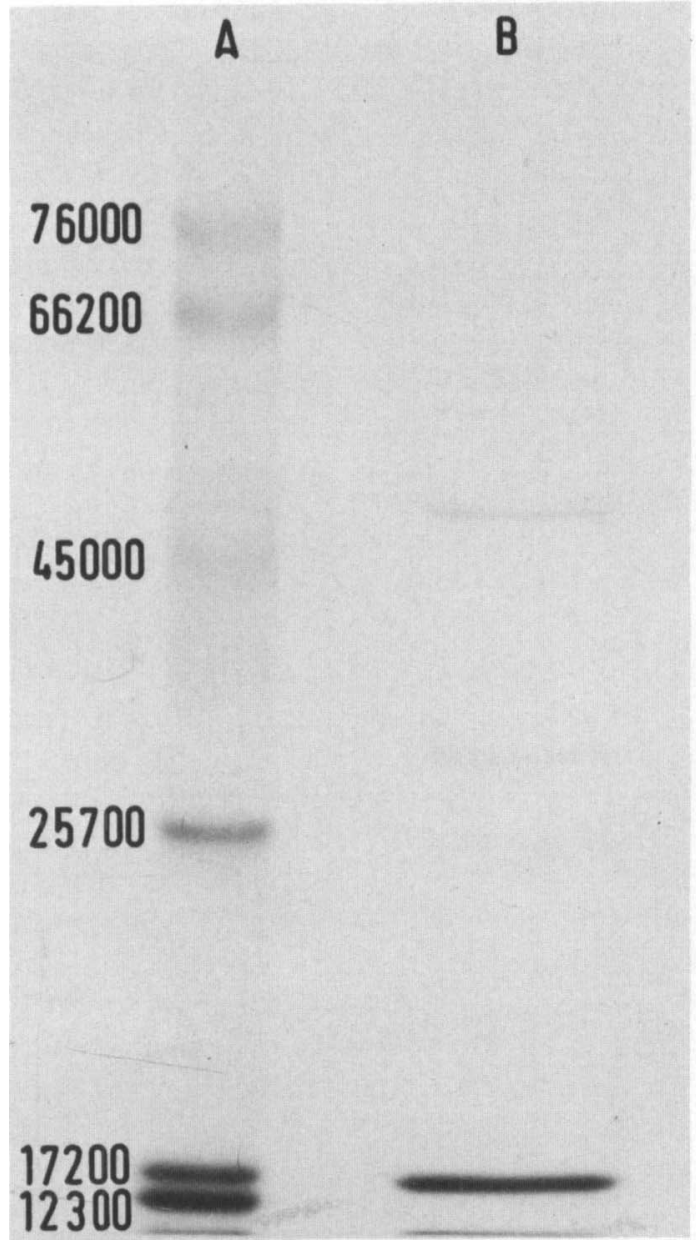

FIG. 4.-SDS-polyacrylamide-gel electrophoresis of sonicate preparation from type-III GBS. Lane A, molecular-weight markers; lane B, sonicate from type-III GBS. 
significant decrease $(\mathrm{p}<0.001)$ in subsequent attachment of type-III GBS to BEC. A dose-response curve is shown in fig. 3.

\section{Pretreatment of BEC with membrane LTA}

No significant difference in binding was evident between treated and untreated cells $(p>0.05)$ (table V).

\section{Polyacrylamide-gel electrophoresis}

SDS-PAGE of the sonicate preparation revealed several protein bands, with one major band of low molecular weight $(c .17000)$ as shown in fig. 4.

\section{DisCusSion}

Buccal epithelial cells have been widely used as target cells in experiments designed to study the adherence of many different bacteria to epithelial surfaces (Alkan, Ofek and Beachey, 1977; Atkinson and Trust, 1980; Craven et al., 1980; Saunders and Miller, 1980; Yamazaki, Ebisu and Okada, 1981). Although a large proportion of buccal cells are non-viable, as judged by trypan-blue exclusion, several layers of dead cells are present in the buccal mucosa (Beachey, 1981). In view of this, it seems appropriate to use them as a target cell for in-vitro assays. The mechanism of attachment of group-A streptococci has been studied with the help of BEC-attachment assays (Beachey, 1975) and it was found that, in the assay described in this paper, group-A streptococci and type-III GBS were bound to BEC to the same extent.

Sodium meta-periodate cleaves the $\mathrm{C}-\mathrm{C}$ bond between vicinal hydroxyl groups of sugars and when $\mathrm{BEC}$ were treated with periodate there was a highly significant drop in the number of GBS that adhered to the cells. Conversely, treatment of the GBS with periodate did not reduce the subsequent binding, suggesting that a sugar molecule on the surface of the buccal cells plays a role in the binding mechanism. Inhibition studies with various simple sugars indicate that N-acetyl-D-glucosamine may be concerned in this.

Mild heat treatment of the bacteria did not reduce binding but heating at $121^{\circ} \mathrm{C}$ for 15 min markedly reduced the degree of attachment; in both instances the bacteria were killed. Possibly the adhesin on the bacterial cell wall is a lectin, a thermostable protein not affected by a temperature of $75^{\circ} \mathrm{C}$ but denatured at $121^{\circ} \mathrm{C}$.

Results obtained with the sonicate from type-III GBS also support the view that a protein rather than a carbohydrate on the bacterial cell surface is the relevant adhesin. Heat treatment of the sonicate greatly reduced its efficiency as a blocking agent whereas the periodate had very little, if any, effect. SDS-PAGE of the sonicate preparation indicated its heterogeneity although there was one dominant protein band of low molecular weight (c. 17000 ). It now seems likely that many bacteria, including such diverse organisms as Escherichia coli (Ofek, Beachey and Sharon, 1978), Eikenella corrodens (Yamazaki et al., 1981), Aeromonas hydrophila (Atkinson and Trust, 1980) and Fusobacterium nucleatum (Mongiello and Falkler, 1979) rely on lectin-type interactions for their adherence to mucosal surfaces. Work in our laboratories has also shown that Corynebacterium parvum may attach to macrophages through a lectin-like binding site in the cell wall of the bacterium (Bagg, Poxton and Weir, 1981). 
The suggestion (Botta, 1979) that some characteristics of adhesion of GBS to human vaginal epithelial cells may be explained by a lectin-type interaction, is supported by our findings. Work recently published (Elbein et al., 1981) describing the binding of GBS to influenza viral glycoproteins that have been inserted into the cell membrane of infected MDCK cells, also supports this view. In the system that we studied, in which type-III GBS attach to BEC, it seems that an N-acetyl-D-glucosamine specific lectin on the bacterial cell surface is involved in attachment of the organism to the eukaryotic cell.

Beachey (1975) has identified membrane LTA as being responsible for binding of group-A streptococci to epithelial cells. Preincubation of BEC with LTA extracted from the cytoplasmic membrane of type-III GBS failed to block significantly the attachment of GBS, so that it seems that the mechanism of their adherence differs from that of the group-A streptococci. This agrees with the finding that loss of LTA from GBS cell walls, caused by treatment with penicillin, did not inhibit adherence of the bacteria to vaginal cells (Zawaneh et al., 1979).

\section{REFERENCES}

Alkan, M., OfeK, I. and Beachey, E. H. 1977. Adherence of pharyngeal and skin strains of group A streptococci to human skin and oral epithelial cells. Infection and Immunity, 18, 555-557.

Anthony, B. F. AND OKaDA, D. M. 1977. The emergence of group B streptococci in infections of the newborn infant. Annual Review of Medicine, 28, 355-369.

AtKINSON, H. M. AND TRUST, T. J. 1980. Hemagglutination properties and adherence ability of Aeromonas hydrophila. Infection and Immunity, 27, 938-946.

Bagg, J., Poxton, I. R. ANd Weir, D. M. 1981. The isolation of a lectin-like molecule from Corynebacterium parvum (NCTC 10390). Journal of Clinical and Laboratory Immunology, 6, $165-168$.

BEACHEY, E. H. 1975. Binding of group A streptococci to human oral mucosal cells by lipoteichoic acid. Transactions of the Association of American Physicians, 88, 285-292.

BEACHEY, E. H. 1981. In Ciba Foundation symposium no. 80, Adhesion and microorganism pathogenicity, Pitman Medical Ltd, London, p. 320.

BotTA, G. A. 1979. Hormonal and type-dependent adhesion of group B streptococci to human vaginal cells. Infection and Immunity, 25, 1084-1086.

COLEY, J., DUCK WORTH, M. AND BADDILEY, J. 1975. Extraction and purification of lipoteichoic acids from gram-positive bacteria. Carbohydrate Research, 40, 41-52.

Craven, D. E., Peppler, M. S., Frasch, C. E., Mocca, L. F., McGrath, P. P. and Washington, G. 1980. Adherence of isolates of Neisseria meningitidis from patients and carriers to human buccal epithelial cells. Journal of Infectious Diseases, 142, 556-568.

Elbein, A. D., Sanford, B. A., Ramsay, M. A. And Pan, Y. T. 1981. Effect of inhibitors on glycoprotein biosynthesis and bacterial adhesion. In Ciba Foundation symposium no. 80, Adhesion and microorganism pathogenicity, Pitman Medical Ltd, London, pp. 270-287.

Ferrieri, P., Cleary, P. P. and Seeds, A. E. 1977. Epidemiology of group-B streptococcal carriage in pregnant women and newborn infants. Journal of Medical Microbiology, 10, 103-114.

Gibbons, R. J. AND van Houte, J. 1971. Selective bacterial adherence to oral epithelial surfaces, and its role as an ecological determinant. Infection and Immunity, 3, 567-573.

LAEMMLI, U.K. AND FAVRE, M. 1973. Maturation of the head of bacteriophage T4. I. DNA packaging events. Journal of Molecular Biology, 80, 575-599.

Lowry, O.H., Rosebrough, N. J., Farr, A. L. and Randall, R. J. 1951. Protein measurement with the Folin phenol reagent. Journal of Biological Chemistry, 193, 265-275.

MÅRD, P. A. AND WeSTRÖM, L. 1976. Adherence of bacteria to vaginal epithelial cells. Infection and Immunity, 13, 661-666. 
Mongiello, J. R. AND FalkLeR, W. A. 1979. Sugar inhibition of oral Fusobacterium nucleatum haemagglutination and cell binding. Archives of Oral Biology, 24, 539-545.

OfEK, I., BeAChey, E. H. AND Sharon, N. 1978. Surface sugars of animal cells as determinants of recognition in bacterial adherence. Trends in Biochemical Science, 3, 159-160.

SAUNDERS, J. M. AND Miller, C. H. 1980. Attachment of Actinomyces naeslundii to human buccal epithelial cells. Infection and Immunity, 29, 981-989.

YamAZAKI, Y., EBISU, S. AND OKADA, H. 1981. Eikenella corrodens adherence to human buccal epithelial cells. Infection and Immunity, 31, 21-27.

Zawaneh, S. M., Ayoub, E. M., Baer, H., Cruz, A. C. and Spellacy, W. N. 1979. Factors influencing adherence of group B streptococci to human vaginal epithelial cells. Infection and Immunity, 26, 441-447. 